Research Article

\title{
Genetic diversity in natural populations of Jacaranda decurrens Cham. determined using RAPD and AFLP markers
}

\author{
Bianca W. Bertoni ${ }^{1}$, Mariana P. de C. Telles ${ }^{2}$, Milena G. Malosso ${ }^{3}$, Simone C.Z. Torres ${ }^{3}$, José O. Pereira ${ }^{4}$, \\ Mirian V. Lourenço ${ }^{1}$, Suzelei de C. França ${ }^{1}$ and Ana M.S. Pereira ${ }^{1}$ \\ ${ }^{1}$ Unidade de Biotecnologia Vegetal, Universidade de Ribeirão Preto, Ribeirão Preto, SP, Brazil. \\ ${ }^{2}$ Laboratório de Genética e Biodiversidade, Instituto de Ciências Biológicas, \\ Universidade Católica de Goiás, Goiânia, GO, Brazil. \\ ${ }^{3}$ Programa de Pós-Graduação em Biotecnologia, Universidade de Ribeirão Preto, Ribeirão Preto, SP, \\ Brazil. \\ ${ }^{4}$ Centro de Apoio Multidisciplinar, Universidade Federal de Amazônia, Manaus, AM, Brazil.
}

\begin{abstract}
Jacaranda decurrens (Bignoniaceae) is an endemic species of the Cerrado with validated antitumoral activity. The genetic diversity of six populations of $J$. decurrens located in the State of São Paulo was determined in this study by using molecular markers for randomly amplified polymorphic DNA (RAPD) and amplified fragment length polymorphism (AFLP). Following optimization of the amplification reaction, 10 selected primers generated 78 reproducible RAPD fragments that were mostly $(69.2 \%)$ polymorphic. Two hundred and five reproducible AFLP fragments were generated by using four selected primer combinations; $46.3 \%$ of these fragments were polymorphic, indicating a considerable level of genetic diversity. Analysis of molecular variance (AMOVA) using these two groups of markers indicated that variability was strongly structured amongst populations. The unweighted pair group method with arithmatic mean (UPGMA) and Pearson's correlation coefficient (RAPD -0.16, $p=0.2082$; AFLP 0.37, $p=0.1006$ ) between genetic matrices and geographic distances suggested that the population structure followed an island model in which a single population of infinite size gave rise to the current populations of $J$. decurrens, independently of their spatial position. The results of this study indicate that RAPD and AFLP markers were similarly efficient in measuring the genetic variability amongst natural populations of $J$. decurrens. These data may be useful for developing strategies for the preservation of this medicinal species in the Cerrado.
\end{abstract}

Key words: Bignoniaceae, carobinha, Cerrado, germplasm bank, preservation.

Received: July 9, 2009; Accepted: March 17, 2010.

\section{Introduction}

The study of population and genetic diversity is a complex subject that involves the analysis of DNA sequences, gene adaptability, inter-individual variation and speciation, and an understanding of the interactions among organisms that compose communities. Furthering knowledge about genes, individuals, species and communities provides an ever greater understanding of biodiversity and, consequently, allows the development of the most adequate strategies for environmental preservation. Molecular markers provide an important tool for assessing the genetic variability and structure of natural populations, and for studying biodiversity in general (Frankham et al., 2002).

Send correspondence to Bianca W. Bertoni. Unidade de Biotecnologia Vegetal, Universidade de Ribeirão Preto, Av. Constábile Romano 2201, 14096-380 Ribeirão Preto, SP, Brazil. E-mail: bbertoni@unaerp.br.
They also provide a basis for developing programs to protect flora threatened with extinction.

The random amplification of polymorphic DNA (RAPD) provides markers that can be used to identify and discriminate genotypes, in addition to providing a means for assessing phenotypic expression and phylogenetic relations in the germplasm under study (Ferreira and Grattapaglia, 1998). Similarly, amplified fragment length polymorphism (AFLP) allows the study of genetic polymorphisms in populations, with the advantage that multiple reaction loci can be detected with high reproducibility (Jain et al.,1994; Hill et al., 1996). Polymorphisms detected by AFLP generally indicate Mendelian inheritance and may be used to study kinship and genetic variability within and between populations. AFLP is also a robust tool for DNA fingerprinting of genomes (Vos et al., 1995). 
Jacaranda decurrens is a medicinal plant endemic to the Cerrado. One of its components, ursolic acid, is considered to have antitumoral activity (Varanda et al., 1992; Subbaramaiah et al., 2000). Indiscriminate collection and frequent deforestation of the Cerrado have damaged the species diversity of this biome and accelerated the ever increasing risk of extinction. In this study, we used RAPD and AFLP markers to calculate the genetic distances among populations of $J$. decurrens in the Cerrado of the State of São Paulo, in southeastern Brazil.

\section{Material and Methods}

Ninety individuals of $J$. decurrens from six populations were used in this study. The collection sites were within the species distribution range in the State of São Paulo (SP) (Figure 1). The areas of collection at each site were randomly chosen to a precision of $10 \mathrm{~m}$ and their precise location was determined with a global positioning satellite (GPS) system. Distances among populations were determined by using the computer program GPS TRACKMAKER 11.7 (Ferreira, 2001) and are shown in Table 1. Exsiccates of all accesses were prepared and deposited in the Herbarium of Medicinal Plants at the University of Ribeirão Preto (HPM - UNAERP, Ribeirão Preto, SP, Brazil). Genomic DNA was isolated from young leaves using the protocol proposed by Doyle and Doyle (1987).

\section{Acquisition of molecular data}

Samples of $J$. decurrens DNA were initially evaluated with 110 primers for RAPD (Operon Life Technology and Biosynthesis Incorporated), 30 of which were selected for further investigation. The reactions were optimized by the amplification protocol of Ferreira and Grattapaglia (1998), and the amplification products (bands) were separated by electrophoresis in $1.5 \%(\mathrm{w} / \mathrm{v})$ agarose gels that were subsequently stained with ethidium bromide. DNA markers (100 bp) were included in each electrophoretic run. All of the reagents were from Amersham Biosciensces. The gels were photographed under ultraviolet light (Image Master VDS, equipment, Pharmacia Biotech) and only re-

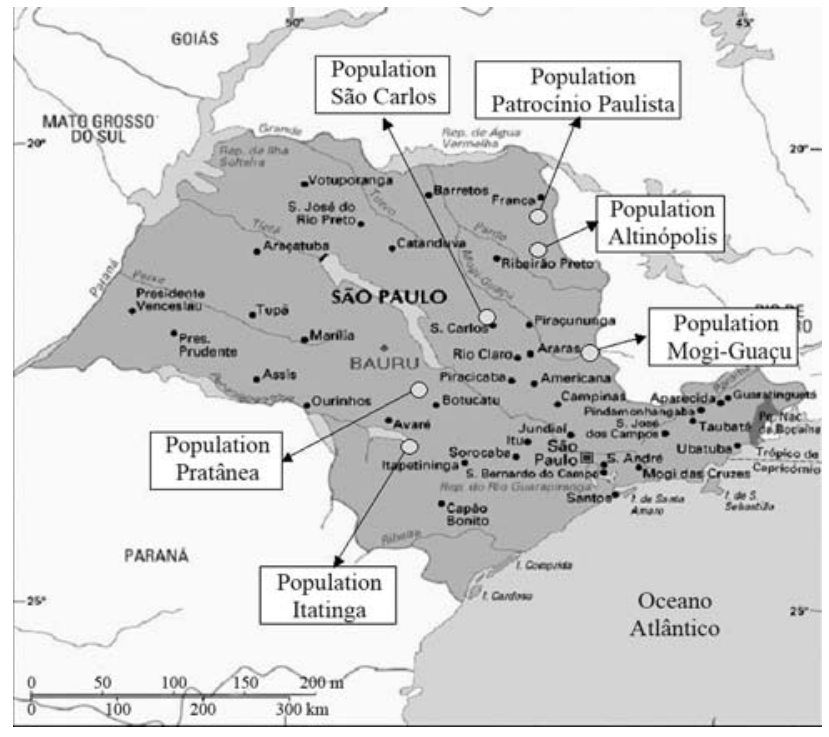

Figure 1 - Geographic location of the $J$. decurrens populations studied in this work.

producible bands were used in subsequently analyses. Weak bands for amplification fragments were excluded. Control samples containing all of the reaction products except DNA were used to confirm the absence of self-amplification and contaminants.

Of 30 RAPD primers selected, 10 showed a high degree of polymorphism and better band intensity (Table 2). After optimizing the parameters of the chain polymerase reaction (PCR), the following protocol was used for RAPD of $J$. decurrens (final reaction volume $=30 \mu \mathrm{L}$ ): $3.0 \mu \mathrm{L}$ of Tp 10X buffer, $3.0 \mu \mathrm{L}$ of $2.5 \mathrm{mM}$ dNTPs, $2.4 \mu \mathrm{L}$ of $25.0 \mathrm{mM} \mathrm{MgCl} 2,5.0 \mu \mathrm{L}$ of primer $(10 \mathrm{ng} / \mu \mathrm{L}), 0.3 \mu \mathrm{L}$ of Taq DNA polymerase $(5 \mathrm{U} / \mu \mathrm{L})$ and $4.0 \mu \mathrm{L}$ of sample DNA $(5 \mathrm{ng} / \mu \mathrm{L})$. The amplifications were done in a thermocycler using the following conditions: 2 cycles at $94^{\circ} \mathrm{C}$ for $2 \mathrm{~min}$, 1 cycle at $37^{\circ} \mathrm{C}$ for $1 \mathrm{~min}, 1$ cycle at $72{ }^{\circ} \mathrm{C}$ for $2 \mathrm{~min}$, and 33 cycles at $94{ }^{\circ} \mathrm{C}$ for $10 \mathrm{~s}, 40{ }^{\circ} \mathrm{C}$ for $20 \mathrm{~s}$ (annealing temperature) and $72{ }^{\circ} \mathrm{C}$ for $2 \mathrm{~min}$.

Table 1 - Identification, geographic location, number of individuals and genetic distances (Nei, 1978) for the J. decurrens populations studied in this work. The geographic distances (in km) and genetic distances (Nei, 1978) among the populations are shown above and below the diagonal, respectively.

\begin{tabular}{|c|c|c|c|c|c|c|c|c|c|c|}
\hline \multirow[t]{2}{*}{ Population } & \multirow[t]{2}{*}{ Longitude } & \multirow[t]{2}{*}{ Latitude } & \multirow{2}{*}{$\begin{array}{l}\text { Altitude } \\
\text { (m) }\end{array}$} & \multirow{2}{*}{$\begin{array}{c}\text { No. of } \\
\text { samples }\end{array}$} & \multicolumn{6}{|c|}{ Distance between populations } \\
\hline & & & & & MG & $\mathrm{SC}$ & PRAT & ITA & PP & ALT \\
\hline Mogi-Guaçu (MG) & $-47^{\circ} 10^{\prime}$ & $-22^{\circ} 15^{\prime}$ & 613.7 & 9 & $* * * * *$ & 66.01 & 174.0 & 190.0 & 175.0 & 137.0 \\
\hline São Carlos (SC) & $-47^{\circ} 47^{\prime}$ & $-22^{\circ} 10^{\prime}$ & 780.0 & 8 & 0.0133 & $* * * * *$ & 122.0 & 152.0 & 172.0 & 126.0 \\
\hline Pratânea (PRAT) & $-48^{\circ} 44^{\prime}$ & $-22^{\circ} 48^{\prime}$ & 740.0 & 17 & 0.0161 & 0.0139 & $* * * * *$ & 49.19 & 280.0 & 235.0 \\
\hline Itatinga (ITA) & $-48^{\circ} 38^{\prime}$ & $-23^{\circ} 16^{\prime}$ & 607.4 & 16 & 0.0192 & 0.0217 & 0.0187 & $* * * * *$ & 320.0 & 273.0 \\
\hline Patrocínio Paulista (PP) & $-47^{\circ} 17^{\prime}$ & $-20^{\circ} 40^{\prime}$ & 760.0 & 10 & 0.0220 & 0.0259 & 0.0230 & 0.0164 & $* * * * *$ & 46.66 \\
\hline \multirow[t]{2}{*}{ Altinópolis (ALT) } & $-47^{\circ} 29$ & $-21^{\circ} 03^{\prime}$ & 616.5 & 30 & 0.0457 & 0.0488 & 0.0419 & 0.0377 & 0.0267 & $* * * * *$ \\
\hline & & & Total & 167 & & & & & & \\
\hline
\end{tabular}


Table 2 - Primers used in this study and RAPD markers for 90 individuals of $J$. decurrens.

\begin{tabular}{|c|c|c|c|c|}
\hline \multirow[b]{2}{*}{ Primers } & \multirow[b]{2}{*}{ Sequence $\left(5^{\prime} \rightarrow 3^{\prime}\right)$} & \multicolumn{3}{|c|}{ Polymorphic bands } \\
\hline & & Total number of bands & Number of polymorphic bands & $\%$ \\
\hline Operon A-01 & CAG GCC CTT C & 12 & 9 & 75 \\
\hline Bio-Synthesis Inc. 2G4-62 & ACG AAC GCA CCA ATG AGC & 9 & 8 & 88 \\
\hline Operon A-02 & TGC CGA GCT G & 10 & 8 & 80 \\
\hline Operon A-08 & GTC ACG TAG C & 11 & 6 & 54 \\
\hline Operon A-18 & AGG TGA CCG T & 8 & 2 & 25 \\
\hline Bio-Synthesis Inc. 3C11-3 & TGC TTC GGG TAG CTC TTG C & 5 & 5 & 100 \\
\hline Operon $\mathrm{H}-03$ & AGA CGT CCA C & 7 & 3 & 42 \\
\hline Operon N-13 & AGC GTC ACT C & 6 & 6 & 100 \\
\hline Operon A-13 & CAG CAC CCA C & 7 & 4 & 57 \\
\hline Operon AV-15 & GGC AGC AGG T & 3 & 3 & 100 \\
\hline Total & & 78 & 54 & - \\
\hline Mean & & 7.8 & 5.4 & 69.2 \\
\hline
\end{tabular}

AFLP was done using a protocol adapted from Vos et al. (1995). Genomic DNA (200 ng) was digested with the restriction enzymes EcoRI and $M s e I$ at $37^{\circ} \mathrm{C}$ for $3 \mathrm{~h}$ in a model PTC-100 thermocycler (MJ Research Inc). The resulting fragments were ligated to specific adapting sequences complementary to the extremities cleaved off by the two enzymes in a reaction done at $23^{\circ} \mathrm{C}$ for $3 \mathrm{~h}$.

The ligated fragments $(50 \mu \mathrm{L})$ were pre-amplified with primers containing a selective base, Eco-A/MseI-A and the PCR products of this pre-amplification were used as a template for the selective amplification in which primers with three selective nucleotides were added to the 3 ' extremity of the primers. Four combinations that were helpful in detecting polymorphisms were used, namely, EcoATC/MseI-ATC, Eco-ATT/MseI-ATG, Eco-ATG/MseIAGT and Eco-AGT/MseI-ATT.

The components of the pre-amplification reaction were: $1 \mu \mathrm{L}$ of EcoRI-primer with one selective base (25 ng/ $\mathrm{LL}), 1 \mu \mathrm{L} \mathrm{MseI}+$ (primer with one selective base) ( $25 \mathrm{ng} / \mu \mathrm{L}), 0.8 \mu \mathrm{L}$ of $2.5 \mathrm{mM}$ dNTPs, $2 \mu \mathrm{L}$ of $10 \mathrm{X}$ buffer B (Promega), 1.2 $\mu \mathrm{L} 25 \mathrm{mM} \mathrm{MgCl}_{2}, 0.6 \mu \mathrm{L}$ Taq DNA polymerase $(5 \mathrm{U} / \mu \mathrm{L})$ (Promega) and $2 \mu \mathrm{L}$ of the ligated DNA. The reaction conditions were as follows: 1) $94^{\circ} \mathrm{C}$ for $2 \mathrm{~min}$, 2) $94{ }^{\circ} \mathrm{C}$ for $\left.1 \mathrm{~min}, 3\right) 56^{\circ} \mathrm{C}$ for $\left.1 \mathrm{~min}, 4\right) 72^{\circ} \mathrm{C}$ for $1 \mathrm{~min}$, and 5) $72^{\circ} \mathrm{C}$ for $5 \mathrm{~min}$; steps 2 to 4 were repeated 26 times. The amplification products were subsequently diluted four-fold and stored at $-20{ }^{\circ} \mathrm{C}$.

For selective amplification by AFLP-PCR the reaction mixture contained: $1 \mu \mathrm{L}$ of $E c o \mathrm{RI}+$ (primer three selective base) $(25 \mathrm{ng} / \mu \mathrm{L}), 1.2 \mu \mathrm{L} \mathrm{MseI}+$ (primer with three selective bases) $(25 \mathrm{ng} / \mu \mathrm{L}), 0.4 \mu \mathrm{L}$ of $2.5 \mathrm{mM}$ dNTPs, $2 \mu \mathrm{L}$ $10 \mathrm{X}$ buffer B (Promega), $1.2 \mu \mathrm{L}$ of $25 \mathrm{mM} \mathrm{MgCl}_{2}, 0.2 \mu \mathrm{L}$ of Taq DNA polymerase $(5 \mathrm{U} / \mu \mathrm{L})$ (Promega) and $1.5 \mu \mathrm{L}$ of pre-amplified DNA. The reaction conditions were as follows: 1) $94{ }^{\circ} \mathrm{C}$ for $\left.2 \mathrm{~min}, 2\right) 94^{\circ} \mathrm{C}$ for $\left.30 \mathrm{~s}, 3\right) 65^{\circ} \mathrm{C}$ for $30 \mathrm{~s}$,
4) $72{ }^{\circ} \mathrm{C}$ for $\left.1 \mathrm{~min}, 5\right) 94{ }^{\circ} \mathrm{C}$ for $\left.30 \mathrm{~s}, 6\right) 56{ }^{\circ} \mathrm{C}$ for $30 \mathrm{~s}$, 7) $72{ }^{\circ} \mathrm{C}$ for $1 \mathrm{~min}$ and 8) $72{ }^{\circ} \mathrm{C}$ for $2 \mathrm{~min}$; steps 2 to 4 were repeated 12 times and steps 5 to 7,23 times. The amplification products were stored at $-20^{\circ} \mathrm{C}$.

The AFLP products were separated by electrophoresis in denaturing $6 \%$ polyacrylamide gels in TBE $1 \mathrm{X}$ buffer for $2 \mathrm{~h}$ at $50{ }^{\circ} \mathrm{C}$ and $80 \mathrm{~W}$ constant voltage. The gels were stained with silver nitrate solution and developed in sodium carbonate, as described by Creste et al. (2001).

\section{Statistical analyses}

The binary data obtained from RAPD and AFLP were used to estimate allele frequencies based on a correction proposed by Lynch and Milligan (1994). A descriptive analysis of total variability was obtained by calculating the percentage of polymorphic loci and Nei's (1978) diversity index. AMOVA was used to separate the total genetic variance into its between- and within-population components; this allowed an assessment of variability, as proposed by Excoffier et al. (1992). The programs TFPGA (Miller 1997), AMOVA-PREP 1.01 (Miller 1998) and WINAMOVA 1.04 (Excoffier 1992) were used for these analyses. Nei's genetic distances (Nei, 1978) were used in a UPGMA grouping analysis to assess the genetic divergence among the populations studied.

\section{Results}

The ten primers chosen produced 78 bands in the six populations, with most (69.23\%) of the bands being polymorphic. The minimum and maximum number of bands per primer was, respectively, 3 and 12 (Table 2). Figure 2 shows a typical example of the polymorphism detected for the primer Operon A-18. The four combinations of AFLP markers used yielded 205 bands, 46.34\% of which were polymorphic. The minimum and maximum number of 


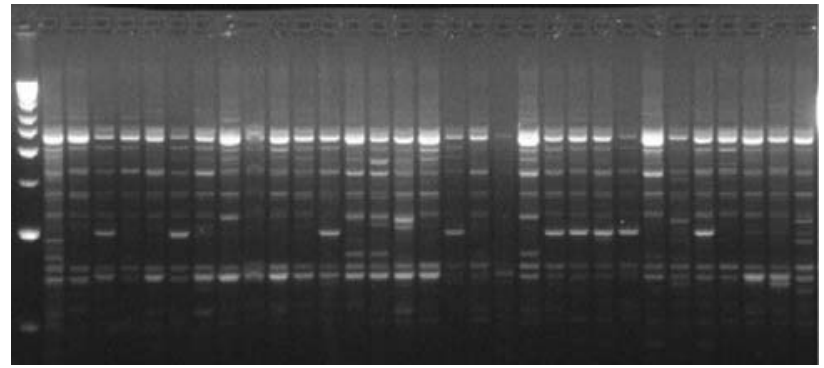

Figure 2 - Profile of RAPD bands obtained with the primer CAG GCC CTT C for natural populations of $J$. decurrens. Lane 1 - molecular weight marker (100 bp ladder).

bands per primer was, respectively, 29 and 73 (Table 3). An example of the polymorphism detected with the E-ATG+M-AGT combination is shown in Figure 3.

\section{Genetic variability within and between populations}

The genetic characteristics of the six populations based on the allele frequencies (assuming Hardy-Weinberg equilibrium for the 205 loci studied) are shown in Table 4. The percentage of loci polymorphic for RAPD and AFLP among the 90 individuals examined was $69.23 \%$ and $46.34 \%$, respectively. The population at Altinópolis had the highest percentage of polymorphic loci for the two markers (62.82\% for RAPD and $33.17 \%$ for AFLP), followed by the populations at Itatinga ( $23.08 \%$ and $28.29 \%$, respectively) and Pratânea (19.23\% and 26.83\%, respectively).

AMOVA based on the RAPD and AFLP markers indicated that $69.69 \%$ and $73.66 \%$ of the genetic variability was in the intra-population component. The $\mathrm{PHI}_{\mathrm{ST}}$ value was 0.303 for RAPD, while for AFLP it was of 0.263 ( $<<0.001)$; both markers indicated a highly significant structuring of the genetic variability in these populations (Table 5).

The UPGMA dendrogram based on Neis genetic distances indicated high variability among the populations, with that from Altinópolis showing the greatest divergence (0.0403) while significant similarity was observed among the populations from Mogi-Guaçú and São Carlos (0.0139) (Figure 4).

Table 3 - Primer combinations used and AFLP markers obtained for 90 individuals of $J$. decurrens.

\begin{tabular}{lccc}
\hline & \multicolumn{3}{c}{ Polymorphic bands } \\
\cline { 2 - 4 } Primer combinations & $\begin{array}{c}\text { Total number of } \\
\text { bands }\end{array}$ & $\begin{array}{c}\text { Number of poly- } \\
\text { morphic bands }\end{array}$ & $\%$ \\
\hline E-ATC+M-ATC & 29 & 13 & 44.8 \\
E-ATT+M-ATG & 30 & 12 & 40 \\
E-ATG+M-AGT & 73 & 38 & 52 \\
E-AGT+M-ATT & 73 & 32 & 43.8 \\
Total & 205 & 95 & - \\
Mean & 51.3 & 23.8 & 46.3 \\
\hline
\end{tabular}

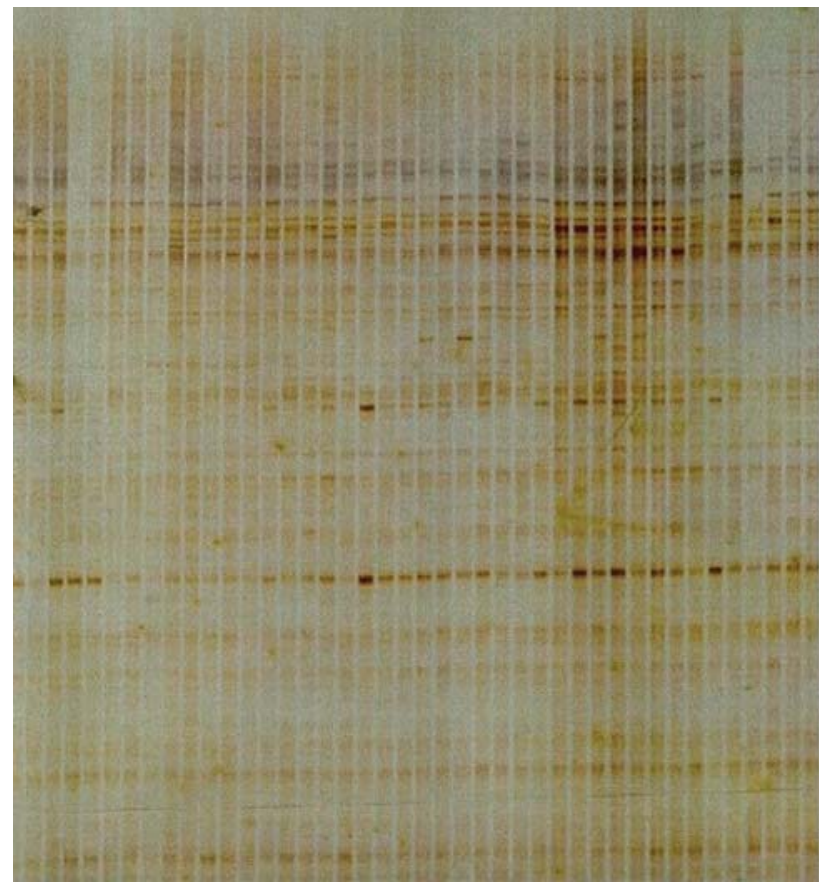

Figure 3 - Profile of AFLP bands obtained with the primer combination E-ATG+M-AGT for natural populations of $J$. decurrens.

The spatial pattern determined by the Mantel test based on 5000 permutations was $0.37(\mathrm{p}=0.1006)$ and $-0.16(\mathrm{p}=0.2082)$ for AFLP and RAPD, respectively. This finding indicated that there was no significant matricial correlation between geographic and genetic distances. These results clearly indicate that geographic distance alone does not explain the spatial pattern of genetic diversity among the populations. They also show that there is no spatial structuring of the genetic variability for AFLP and RAPD markers in the $J$. decurrens populations studied here. Both findings support a model of partially isolated islands that evolved independently in genetic space.

Table 4 - Basic descriptive statistics for RAPD and AFLP analyses of populations of J. decurrens in the State of São Paulo. Hardy-Weimberg equilibrium was assumed. The mean sample size $(\overline{\mathrm{n}})$, number of observed alleles per locus (na) and percentage of polymorphic loci (P) are shown. The parameters were calculated with the POPGENE program (Yeh et al., 1999).

\begin{tabular}{lcccccc}
\hline & & \multicolumn{2}{c}{ RAPD } & & \multicolumn{2}{c}{ AFLP } \\
\cline { 3 - 4 } \cline { 7 - 8 } Population & $\bar{n}$ & na & P & & na & P \\
\hline Mogi Guaçú & 9 & 1.1667 & 16.67 & & 1.2683 & 26.83 \\
São Carlos & 8 & 1.1538 & 15.38 & & 1.2293 & 22.93 \\
Pratânea & 17 & 1.1923 & 19.23 & & 1.683 & 26.83 \\
Itatinga & 16 & 1.2308 & 23.08 & & 1.2829 & 28.29 \\
Patrocínio Paulista & 10 & 1.1923 & 19.23 & & 1.585 & 25.85 \\
Altinópolis & 30 & 1.6282 & 62.82 & & 1.3317 & 33.17 \\
Total & 90 & 1.6923 & 69.23 & & 1.4634 & 46.34 \\
\hline
\end{tabular}




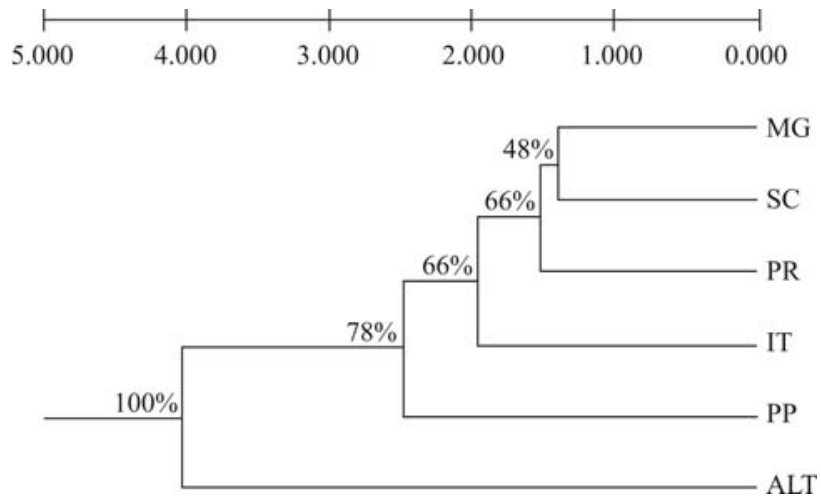

Figure 4 - Pattern of genetic divergence among six populations of $J$. decurrens in the State of São Paulo based on the analysis of RAPD and AFLP markers. The relationships were assessed by the UPGMA method based on Nei's genetic distances (Nei,1978)

\section{Discussion}

This is the first study to use RAPD and AFLP molecular markers to examine the genetic variability of natural populations of $J$. decurrens in the State of São Paulo. The high variability reported here indicates that these markers are useful for analyzing the genetic constitution of the six populations that were studied; this conclusion was supported by the number of polymorphic bands observed (Tables 2 and 3), by the allele frequencies (assuming Hardy-Weinberg equilibrium) (Table 4) and by AMOVA (Table 5).

Many studies with RAPD and AFLP markers have confirmed the efficacy of these techniques in assessing the variability and genetic structure of populations in a variety of plants, including cocoa (Russell et al., 1993), Azadirachta indica (Singh et al., 2002), Saccharum spp. (Lima et al., 2002), rice (Ge et al., 1999), mahogany (Gillies et al., 1999), pepper (Wadt and Kageyama, 2004), Ilex paraguariensis (Gauer and Cavalli-Molina, 2000), Hypericum perforatum (Arnholdt-Schmitt, 2000), Digitalis minor (Sales et al., 2001) and Tabebuia impetiginosa (Ci- ampi et al., 2003), the last four species being medicinal plants.

Variation in the allele frequency between populations ( $\mathrm{F}_{\mathrm{ST}}$, proposed by Wright) reflects the probability that two random genes from two populations are identical by descent (Futuyma, 1992). Population subdivision may affect the allele frequencies and consequently the proportion of genetic variability between populations (Solferini and Selivon, 2001). Previous analyses of genetic variability between and within $J$. decurrens populations estimated the variation in $\mathrm{PHI}_{\mathrm{ST}}$ for RAPD and AFLP markers to be 0.303 and 0.263 , respectively, i.e., greater than the upper limit of 0.25 proposed by Wright (Solferini and Selivon, 2001); these elevated values indicate a high degree of high population structuring.

The greatest genetic variability in the Jacaranda populations (Table 5) occurred within populations $(69.69 \%$ for RAPD and $73.66 \%$ for AFLP). A similar degree of structures was reported for Tabebuia impetiginosa, another Bignoniaceae native to human-modified habitats; in this case, the genetic variability within populations was also greater than between them ( $\sim 94 \%$ greater) (Ciampi et al., 2003).

The dispersion of $J$. decurrens and T. impetiginosa seeds is completed by wind because the seeds are wispy and have membranous husks that favor their migration over large distances. According to Loveless and Hamrick (1984), seed dispersion by wind increases variation within populations. Conversely, depending on the wind velocity and the seed characteristics, migration over long distances can avoid population divergence. $J$. decurrens shows an ecological interaction with fire via a phenomenon known as pyrophytic adaptation in which fire, in addition to opening fruits that are close to the soil surface because of their weight, also eliminates the barrier created by leaves and small twigs of the plant itself; fire also reduces the interference of neighboring small plants on jaracanda seed dispersal (Coutinho 1977). In the absence of burnings, seeds are prevented from being taken over long distances by the wind; consequently, variability between populations in-

Table 5 - AMOVA between and within populations of $J$. decurrens $(\mathrm{n}=90$ individuals/population) based on RAPD and AFLP results. DF, degrees of freedom, SQ, sum of squares, SQM, sum of mean squares, p, level of significance for the estimate of genetic variation based on 1000 permutations. PHI $_{\mathrm{st}}$ statistic, genetic variation estimated for sources of variation analogous to the Wright statistic $\mathrm{F}_{\mathrm{ST}}$. The analyses were done using the programs AMOVA-PREP 1.01 (Miller, 1998) and WINAMOVA 1.04 (Excoffier, 1992).

\begin{tabular}{|c|c|c|c|c|c|c|c|}
\hline Source of variation (RAPD) & $\mathrm{DF}$ & SQ & SQM & Variance components & $\%$ of total variation & $\mathrm{p}$ & $\mathrm{PHI}_{\mathrm{st}}$ statistic \\
\hline Between populations & 5 & 162.29 & 32.45 & 1.96 & 30.31 & $<0.001$ & 0.303 \\
\hline Within populations & 84 & 378.99 & 4.1 & 4.51 & 69.69 & - & - \\
\hline Total & 89 & 541.28 & & & & & \\
\hline Source of variation (AFLP) & DF & SQ & SQM & Variance components & $\%$ of total variation & $\mathrm{p}$ & $\mathrm{PHI}_{\text {st }}$ statistic \\
\hline Between populations & 5 & 283.80 & 56.76 & 3.33 & 26.34 & $<0.001$ & 0.263 \\
\hline Within populations & 84 & 782.49 & 9.315 & 9.315 & 73.66 & - & - \\
\hline Total & 89 & 1 & 066.29 & & & & \\
\hline
\end{tabular}


creases and could explain the marked variation seen here between populations of $J$. decurrens.

There was no obvious relationship between the genetic and geographic distances among the populations studied here. This finding suggests that the structure of the $J$. decurrens populations in this study followed the island model proposed by Wright (Solé-Cava, 2001) in which the differentiation between populations does not depend on the distance that separates them. A single population of infinite size or other islands could have given rise to the present $J$. decurrens populations, without any particular relationship to their spatial position (Slatkin, 1985).

According to Solé-Cava (2001), populations of species threatened with extinction are frequently structured since, in general, environmental degradation leads to the formation of refuges (fragments) where small populations of these species persist but are unable to exchange genetic material with other plants located in unaltered areas. The $J$. decurrens populations examined here constituted refuges, each with a high level of structuring.

The results of this study may be useful in establishing conservation strategies of endemic species such as $J$. decurrens in the State of São Paulo. One possibility is to preserve the genetic variability found in the area of plant occurrence (in situ conservation) since local adaptations tend to favor the establishment of a species in its natural habitat. With the exception of the Mogi Guaçú population, which is located on the Mogi Guaçú Biological Reserve, all of the other populations are located on private lands that have experienced different degrees of human intervention. Since it is likely that in the near future these populations will cease to exist because of increased land use, we suggest that samples of the material analyzed here be preserved in a germplasm bank.

\section{Acknowledgments}

This project was financed by UNAERP and the Biota program of the Fundação de Amparo à Pesquisa do Estado de São Paulo (FAPESP, grant no. 99-10610/1).

\section{References}

Arnholdt-Schmitt B (2000) RAPD analysis: A method to investigate aspects of the reproductive biology of Hypericum perforatum L. Theor Appl Genet 100:906-911.

Ciampi AY, Azevedo VCR and Silva VP (2003) Análise genética populacional de Tabebuia impetiginosa utilizando marcadores moleculares RAPD. In: Boletim de Pesquisa e Desenvolvimento. Embrapa Recursos Genéticos e Biotecnologia, Brasília, 18 pp.

Coutinho LM (1977) Aspectos ecológicos do fogo no Cerrado. II As queimadas e a dispersão de sementes em algumas espécies anemocóricas do estrato herbáceo-subarbustivo. Bolm Botan 5:57-64 (Abstract in English).

Creste S, Tulmann Neto A and Figueira A (2001) Detection of single sequence repeat polymorphisms in denaturing polyacryl- amide sequencing gels by silver staining. Plant Mol Biol Rep 19:299-306.

Doyle JJ and Doyle JL (1987) Isolation of plant DNA from fresh tissue. Focus 12:13-15.

Excoffier L, Smouse PE and Quattro JM (1992) Analysis of molecular variance inferred from metric distances among DNA haplotypes: Application to human mitochondrial DNA restriction data. Genetics 131:479-491.

Ferreira ME and Grattapaglia D (1998) Introdução ao Uso de Marcadores Moleculares em Análise Genética. Embrapa Cenargen, Brasília, 220 pp.

Frankham R, Ballou JD and Brioscoe DA (2002) Introduction to Conservation Genetics. Cambridge University Press, Cambridge, $640 \mathrm{pp}$.

Futuyma DJ (1992) Biologia Evolutiva. 2a edição. Sociedade Brasileira de Genética, Ribeirão Preto, 631 pp.

Gauer L and Cavalli-Molina S (2000) Genetic variation in natural populations of mate (Ilex paraguariensis A. St.-Hil., Aquifoliaceae) using RAPD markers. Heredity 84:647-656.

Ge S, Oliveira GCX, Schaal BA, Gao L and Hong D (1999) RAPD variation within and between natural populations of wild rice Oryza rufipogon from China and Brazil. Heredity 82:638-644.

Gillies ACMC, Navarro AJ, Lowe AC, Newton M, Hernández JW and Cornelius JP (1999) Genetic diversity in Mesoamerican populations of mahogany (Swietenia macrophylla), assessed using RAPDs. Heredity 83:722-732.

Hill M, Witsenboer H, Zabeau M and Vos P (1996) PCR-based fingerprinting using AFLPs as a tool for studying genetic relationships in Lactuca spp. Theor Appl Genet 93:12021210.

Jain A, Bhatia S, Banga SS, Prakash S and Lakshmikumaran M (1994) Potential use of random amplified polymorphic DNA (RAPD) technique to study the genetic diversity in Indian mustard (Brassica juncea) and its relationship to heterosis. Theor Appl Genet 88:116-122.

Lima MLA, Garcia AAF, Oliveira KM, Matsuoka S, Arizono H, de Souza CL and Souza AP (2002) Analysis of genetic similarity detected by AFLP and coefficient of parentage among genotypes of sugar (Saccharum spp). Theor Appl Genet 104:30-38.

Loveless MD and Hamrick JL (1984) Ecological determinants of genetic structure in plant populations. Annu Rev Ecol Syst 15:65-95.

Lynch M and Milligan BG (1994) Analysis of population genetic structure with RAPD markers. Mol Ecol 3:91-99.

Nei M (1978) Estimation of average heterozygosity and genetic distance from a small number of individuals. Genetics 89:583-590.

Russell JR, Hosein F, Johnson E, Waugh R and Powell W (1993) Genetic differentiation of cocoa (Theobroma cacao L.) populations revealed by RAPD analysis. Mol Ecol 2:89-97.

Sales E, Nebauer SG, Mus M and Segura J (2001) Population genetic study in the Balearic endemic plant species Digitalis minor (Scrophulariaceae) using RAPD markers. Am J Bot 88:1750-1759.

Singh A, Chaudhury A, Srivastava PS and Lakshmikumaran M (2002) Comparison of AFLP and SAMPL markers assessment of intra-population genetic variation in Azadirachta indica A. Juss. Plant Sci 162:17-25. 
Slatkin M (1985) Gene flow in natural populations. Annu Rev Ecol Syst 16:393-430.

Solé-Cava AM (2001) Biodiversidade molecular e genética da conservação. In: Matioli SR (ed) Biologia Molecular e Evolução. Holos Press, Ribeirão Preto, pp 172-192.

Solferini VN and Selivon D (2001) Polimorfismos de isozimas. In: Matioli SR (ed) Biologia Molecular e Evolução. Holos Press, Ribeirão Preto, pp 139-142.

Subbaramaiah K, Michaluart P, Sporn MB and Dannenberg AJ (2000) Ursolic acid inhibits cyclooxygenase-2 transcription in human mammary epithelial cells. Cancer Res 60:23992404.

Varanda EM, Zuniga GE, Salatino A, Roque NF and Corcuera LJ (1992) Effect of ursolic acid from epicuticular waxes of Jacaranda decurrens on Schizaphis graminum. J Nat Prod 55:800-803.

Vos P, Hogers R, Bleeker M, Reijans M, Lee T Van de, Hornes M, Frijters A, Pot J, Peleman J, Kuiper M, et al. (1995) AFLP: A new technique for DNA fingerprinting. Nucleic Acids Res 23:4414-4414.

Wadt LHO and Kageyama PY (2004) Estrutura genética e sistema de acasalamento de Piper hispidinervum. Pesq Agropec Bras 39:151-157 (Abstract in English).

\section{Internet Resources}

Excoffier L (1992) WINAMOVA 1.04: Analysis of molecular variance.

http://www.tiem.utk.edu/ gross/WWW_pt2d.html (February 10,2005$)$.

Ferreira Jr O (2001) GPS TrackMaker ${ }^{\circledR}$ for Windows ${ }^{\circledR}$ v. 11.7. http//:www.gpstm.com.br (February 10, 2005).

Miller MP (1997) TFPGA 1.03: Tools for populations genetic analyses. http://www.marksgeneticsoftwear.net/tfpga.htm (February 22, 2005).

Miller MP (1998) AMOVA-PREP 1.01: A program for the preparation of AMOVA input from dominant-marker of raw data. http://www.marksgeneticsoftwear.net/amovaprep.htm (February 2, 2005).

Yeh FC, Yang R and Boyle T (1999) POPGENE 1.32: Population Genetic Analysis. $\mathrm{ftp} / / / \mathrm{ftp}$. microsoft.com/Softlib/MSLFILES/HPGL.EXE (February 2, 2002).

\section{Associate Editor: Márcio de Castro Silva Filho}

License information: This is an open-access article distributed under the terms of the Creative Commons Attribution License, which permits unrestricted use, distribution, and reproduction in any medium, provided the original work is properly cited. 